\title{
A CRIMINAL LAW RESPONSE TO THE HARMFUL PRACTICES OF UKUTHWALA
}

\author{
Mkhuseli Jokani \\ BProc LLM LLD \\ Senior State Advocate, National Prosecuting \\ Authority \\ Elmarie Knoetze \\ BJuris LLB LLM LLD \\ Professor, Private Law, Nelson Mandela \\ University \\ Deon Erasmus \\ BJuris LLB LLD \\ Associate Professor, Criminal and Procedural \\ Law, Nelson Mandela University
}

\section{SUMMARY}

This article deals with the criminal consequences of the customary law practice of ukuthwala that has been in the news in the recent past in both print and electronic media, whereby elderly men forcibly take young girls for purposes of marriage. A distinction is drawn between ukuthwala, forced and early marriage in order to clarify the concept of ukuthwala. The article considers the question of whether additional legislation is needed to criminalise the thwala custom. The article concludes that forced and early marriages constitute crimes, are illegal, harmful and have no place in a modern constitutional order. It further provides a response to the legal challenges arising from the customary law practice by means of common law and legislation. In conclusion, it recommends that South Africa does not need separate legislation to criminalise ukuthwala and its variants.

\section{$1 \quad$ INTRODUCTION}

This contribution deals with harmful practices resulting from the application of the custom of ukuthwala and the challenges faced by South African courts in attempting to address these harmful practices through the application of 
existing common and customary law. ${ }^{1}$ In its traditional form, ukuthwala does not target young girls but is a condoned, abnormal path to marriage targeted at certain women of marriageable age. ${ }^{2}$

The practice of ukuthwala and its variants have left a trail of destructive consequences that impact gravely not only on the girl child victims but also more broadly on communities in the Eastern Pondoland area of Lusikisiki, Flagstaff and Bizana. These communities are affected in one way or another by this practice and its variants in the form of forced and early marriages. The researcher has studied a number of case dockets, has given instructions to the South African Police Services for further investigations and has prosecuted one case in the Regional Division of Lusikisiki, cited as $S v$ Nkosiyabekwa Mbele ${ }^{3}$ that forms part of the empirical research project.

It is submitted that the facts of these case dockets studied in Eastern Pondoland represent distortions and harmful practices, which had resulted in the sexual exploitation and abuse of children. ${ }^{4}$ It is submitted that the practice constitutes a crime, is illegal and harmful and as such has no place in a modern constitutional democracy. The question that begs an answer is how the common law and legislation in South Africa respond to the challenges posed by the practice of ukuthwala. It needs to be determined whether South Africa needs specific legislation to deal with the problem caused by ukuthwala or whether the existing laws, both common law and legislation, sufficiently deal with the problem. These latter questions arise from the fact that the South African government has mandated the South African Law Reform Commission to investigate the issue. This article will attempt to address the question set out above. An examination of the applicable common law, as well as the existing legislative framework, will be undertaken.

\section{THE DEFINITION OF UKUTHWALA}

Ukuthwala is a Xhosa word, literally meaning, "to carry". ${ }^{5}$ Ukuthwala is mainly practised among the Xhosa people in the Eastern Cape Province but it does occur with other Nguni tribes in South Africa. ${ }^{6}$ Ukuthwala is one of the methods of the formation of a customary marriage. ${ }^{7}$ In the Xhosa custom, there are requirements that have to be met before any person can engage in a marriage.

1 This research is based on an empirical study which forms part of the researcher's doctoral thesis (The Customary Law Practice of ukuthwala - An Antithesis in the South African Constitutional Order) submitted to fulfil the requirements for the LLD degree at the Nelson Mandela University.

2 Maluleka "Culture, Tradition, Custom, Law and Gender Equality" 2012 Potchefstroom Electronic LJ 10.

3 RCL 75/2011 unreported.

4 Van der Watt and Ovens "Contextualising the Practice of Ukuthwala within South Africa" 2012 South African LJ 13.

5 Mubangizi "A South African Perspective on the Clash between Culture and Human Rights, with Particular Reference to Gender-Related Cultural Practices and Traditions" 2012 Journal of International Women Studies 39.

6 Ibid.

7 Koyana and Bekker "The Indomitable Ukuthwala Custom" 2007 De Jure 139. 
There are three forms of ukuthwala:

(i) Ukuthwala ngemvumelwano / ukugcagca (consent by the girl and by parents);

(ii) Ukuthwala kobulawu (consent between parents but without the consent of the girl); and

(iii) Ukuthwala okungenamvumelwano (neither the girl nor her parents give consent). ${ }^{8}$

The first form of ukuthwala is where the girl is aware of her abduction being planned by her suitor. ${ }^{9}$ In other words, the parties are in cahoots with one another and the force used basically serves as a veil for the girl's consent. ${ }^{10}$ The second form of ukuthwala is where the families would agree on the anticipated marriage between the girl and the young man. ${ }^{11}$ In the latter instance the girl, and sometimes the young man, are unaware of the agreement. ${ }^{12}$ Subsequent to the girl's thwala and confirmation by both families, the girl will be watched until she is used to the idea of marriage. ${ }^{13}$ The third form of ukuthwala is where neither the girl nor her parents have consented. ${ }^{14}$ In other words, the girl is forcefully taken against her will to the home of the young man.

\section{COMMON-LAW CRIMES AND UKUTHWALA}

The colonisation of Africa by the western world meant the imposition of European public and criminal law in the new colonies without exception, and the private indigenous law was recognised as long as it was not in conflict with the European sense of morality and justice. ${ }^{15}$ The application of African customary law was subjected to European values and notions of morality, which were used to purge the customary law of perceived undesirable attributes. $^{16}$ South Africa remains a multicultural society and, as such, customary law is still practised and adhered to by many people in the country, particularly in rural areas. ${ }^{17}$

Since the advent of democracy, customary law is constitutionally recognised as part of the South African legal system and is seen as standing alongside the Roman-Dutch common law. ${ }^{18}$ Historically, ukuthwala has been held to constitute either of the common-law crimes of abduction, kidnapping, assault with intent to cause grievous bodily harm, assault common, and common-law rape which has now been repealed by the Sexual Offences

\footnotetext{
Oosthuizen and Ngema "Ukuthwala: Structured for Relevance" 2010 Speculum Juris 87.

Van der Watt and Ovens 2012 South African LJ 13.

Ibid.

Ibid.

Ibid.

Ibid.

Mwambene and Sloth-Nielsen "Benign Accommodation? Ukuthwala, 'Forced Marriage' and the South African Children's Act" 2011 Journal of Family Law and Practice 7.

15 Oosthuizen and Ngema 2010 Speculum Juris 84.

16 Sanders The Conflict of Laws in South Africa (1990) 2.

17 Rautenbach and Mathee "Common Law Crimes and Indigenous Customs: Dealing with the Issues in South African Law" 2010 Journal of Legal Pluralism 112.

18 Ibid.
} 
and Related Matters Act. ${ }^{19}$ The following sub-paragraphs will explore the conflict between ukuthwala and the common law by means of critically evaluating common law offences that might be committed in relation to the practice in South Africa.

\section{Abduction and ukuthwala}

Abduction is a common-law crime with its origin embedded in the constitutions of Justinian, which penalised the removal or raptus, with or without violence, of a woman from the control of her guardian for the purpose of marrying her or having sexual intercourse with her. ${ }^{20}$ Abduction has its origins in a time and society in which women were considered to be an economic asset of the family. ${ }^{21}$ The crime sought to protect the family's economic interests by preventing outsiders removing or facilitating the escape of females, and especially young women, from the control of the family. ${ }^{22}$ During those days, minor women played a very subservient role in society and were to a large extent subjected to the authority of their parents or guardians. ${ }^{23}$ Minor girls enjoyed little freedom of movement and were often regarded as their parents' economic assets. ${ }^{24}$ The purpose of the crime was to prevent strangers from removing minor girls from the parents' control, thereby depriving them of their rights, economic or otherwise, in respect of the girl.

The crime's application was later extended to also protect parents' rights in respect of minor boys. ${ }^{26}$ The status of young women and children is different in modern society in that they have constitutional rights and are therefore more independent of parental authority. ${ }^{27}$ The crime of abduction still exists, in effect protecting the parental rights that parents enjoy in respect of their minor children and in particular the power to consent to the minor's marriage. ${ }^{28}$ The crime of abduction is committed only where the abduction is for the purposes of marriage or a sexual liaison with the abductee. ${ }^{29}$ This feature distinguishes abduction from kidnapping. ${ }^{30}$ The specific purpose of the crime of abduction is simply to protect the power of parents to consent to the marriage of their child. ${ }^{31}$ Therefore, the crime represents a wrong committed against the parent or guardian of the minor and not against the minor, because the latter's consent to the acts of the wrongdoer is no defence. ${ }^{32}$ The interests protected by the crime of abduction

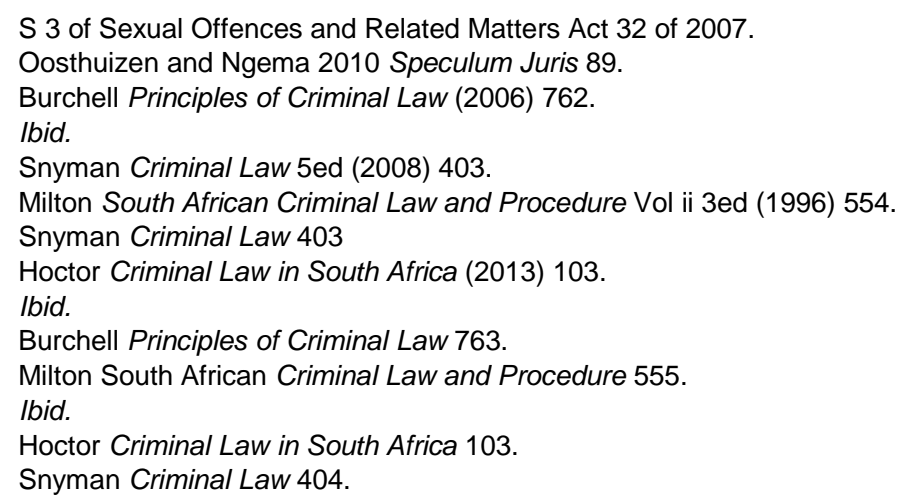


are twofold, namely the factual exercise of control over the minor, and the parents' or guardian's rights to consent to the minor's marriage. ${ }^{33}$

The essential elements of abduction are the unlawful taking of a minor out of the control of a custodian without the consent of the person or persons whose consent to the minor's marriage is necessary. ${ }^{34}$ The most important event, which in practice may deprive the taking of unlawfulness, is consent. ${ }^{35}$ This does not mean consent by the minor for this is irrelevant, but consent by the parents or guardians of the minor child is required. South African law recognises a form of abduction (ukuthwala) as a legitimate means to force the hand of the parents or guardians to agree to marriage negotiations. ${ }^{36}$

Maluleka ${ }^{37}$ points out that, in the traditional sense ukuthwala applies to girls or young women of a marriageable age. Therefore the crime of abduction does not arise where the young women is of age because abduction is committed against parental authority. However, the difficulty with African customary law is that it does not place the same emphasis on age as in a European context. In customary law, the girl is not regarded as a minor if she has reached puberty and has acquired a level of maturity where she can start a family. However, according to the national laws, the age of majority is when a person reaches the age of eighteen. It is safe to suggest that the crime of abduction does not arise in a situation where there is a conspiracy between the girl and her suitor. The reason for this argument is that this form of thwala is based on mutual love notwithstanding the lack of consent from parents.

In the situation where there is an agreement between the family of the girl and the family of the groom and the girl is unaware of such an agreement, the crime of abduction does not arise. In the event where neither the girl nor her parents have prior knowledge of ukuthwala, the crime of abduction arises. In Busisiwe Nobulumko Feni $v$ Ntombekhaya Mgudlwa ${ }^{38}$ the court acknowledged the validity of the custom of ukuthwala as constituting a valid customary marriage. The conflict between the common law crime of abduction and ukuthwala is clear. ${ }^{39}$ In terms of the common law if one removes a minor from the control of her guardian for the purpose of marriage or to have sexual intercourse with her he commits an offence. ${ }^{40}$ In terms of the ukuthwala custom, if a man removes a girl from the control of her guardian for the purpose of marriage, he enters into a valid and binding customary marriage.

The practice in Lusikisiki falls within the crime of abduction since minors, in the true sense of the word, are targeted by men old enough to be their fathers. The difficulty in some of the cases is that the parents are involved and, as such, the crime of abduction does not arise since parental consent

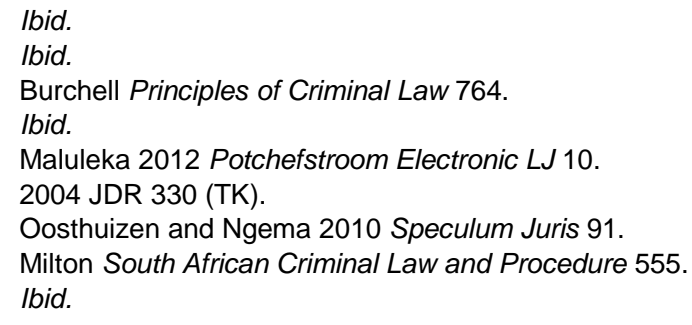


was obtained to abduct the minor children. The accused must know or foresee that the abductee is a minor, that she is still under somebody's control and that due consent to the taking is lacking. ${ }^{42}$ In that scenario, a crime of abduction will arise. All the elements of the crime must be present, namely: unlawfulness, removal, a minor, out of control of parent or guardian and intention. ${ }^{43}$ There must be no justification for the accused's conduct. ${ }^{44}$

In circumstances where the parents or guardian of the minor child is involved in the thwala, the crime of abduction will not suffice, because this crime is committed against the parental authority not against the minor child. In such circumstances, it is advisable that the prosecutor consider other criminal charges such as kidnapping and other statutory crimes provided for in the Children's Act and Prevention and Combating of Trafficking in Persons Act. In the recent past, parents were found to be complicit in the thwala of their children and, quite correctly, the prosecution has opted to charge the perpetrators with other charges than the common law crime of abduction.

\section{Kidnapping and ukuthwala}

Kidnapping consists of unlawfully and intentionally depriving a person of his or her freedom of movement and/ or if such person is a child, the custodians of their control over the child. ${ }^{45}$ This is a crime against the person's freedom of movement and can be committed against adult males and females and against children. ${ }^{46}$ When the child is kidnapped, it is not just the child who is deprived of freedom of movement, but also the child's parent or guardian who is deprived of control over the child. ${ }^{47}$ The crime derives from the lex Fabia de plagariis in Roman law and was known in common law as plagium. ${ }^{48}$ In South Africa, it has in the past been given many names, such as "manstealing", "womanstealing", "childstealing", "plagium" and later "kidnapping". ${ }^{49} \mathrm{~A}$ human being cannot be the object of theft, and therefore kidnapping is not a form of theft. ${ }^{50}$ It is submitted that the most satisfactory definition of the crime is kidnapping. ${ }^{51}$ Kidnapping is a form of conduct that involves the invasion of the personal freedom of the victim while inflicting mental anguish of a greater or lesser degree, and exposing the victim to the risk of physical harm and, in cases of ransom and terrorist kidnapping, even death.$^{52}$ In South Africa, the crime of kidnapping in the course of its evolution protects twofold interests, namely personal liberty and parental control of the minor. ${ }^{53}$

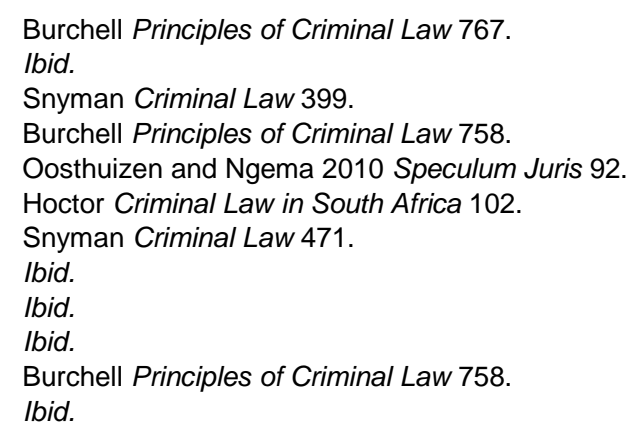


The main difference between kidnapping and abduction is that in the case of abduction the removal from the guardian's control is normally done with the intention by the abductor to marry the minor or to have sexual intercourse with her. ${ }^{54}$ In the case of kidnapping, the reason for removal is immaterial. ${ }^{55}$ The conduct of ukuthwala can be equated with the conduct required for kidnapping. ${ }^{56}$ In all three forms of ukuthwala, the girl is literally carried away. ${ }^{57}$ Such conduct amounts to kidnapping except in instances where the girl consents to the thwala and is of age..$^{58}$ In this case, the crime of kidnapping will have been committed. However, if the girl is thwalae'd without her consent, but with the consent of the parents, as in the second form of ukuthwala, or, as in the last form, without her consent or the consent of her parents by being forcibly taken by the groom and his friends to his home this constitutes kidnapping. If she consents to marriage subsequent to a thwala, the conduct with which she was taken may constitute kidnapping, however in terms of customary law, it is not viewed as such.

The rationale for this is to also prosecute parents who are involved in the practice of ukuthwala, where it involves minor children with the consent of the parents. A parent cannot commit the crime of kidnapping in respect of his or her own child. ${ }^{60}$ The practical difficulty is that in the absence of specific statutory provisions, it is extremely difficult to prosecute parents who are complicit to the practice of ukuthwala by relying on common law. It is therefore very difficult to rely on the common-law crimes of abduction and kidnapping when parents are involved in the forced and early marriage of their own children.

\section{Common assault and ukuthwala}

Assault consists of any unlawful and intentional act or omission that results in another person's bodily integrity being directly or indirectly impaired, or which inspires a belief in another person that such impairment of her bodily integrity is immediately to take place. ${ }^{61}$ The crime of assault can be committed in two distinct ways, namely by the application of force or by inspiring a belief that force is to be applied. Normally when a girl is being thwalae'd, the suitor and his friends waylay the girl without her knowledge, and sometimes with her knowledge and agreement, and carry her to his home. ${ }^{62}$ In the event where the girl had no prior knowledge of the thwala, she is carried forcibly to the home of the suitor. ${ }^{63}$ If the girl puts up resistance, which she normally does, she is overwhelmed by brutal force. ${ }^{64}$

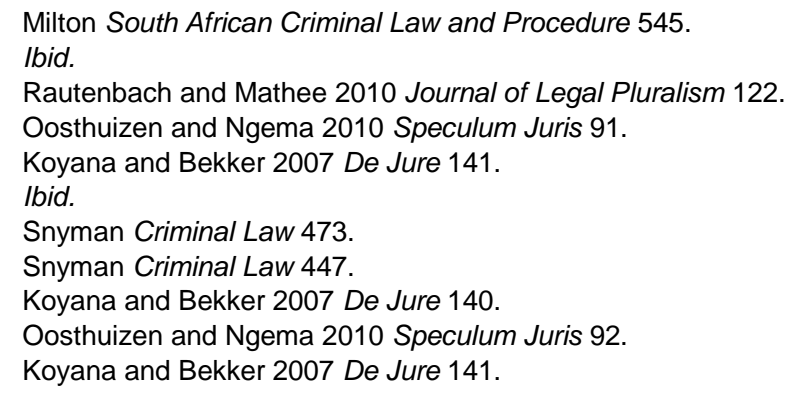


Therefore, in this instance, the suitor and his assailants are committing the crime of assault by applying force to the person of the girl who is the subject of thwala. In some instances, the belief is inspired in the girl that force will immediately be applied to her if she continues to resist the thwala. However, in the event where the girl had a prior knowledge of the thwala and put up a pretended resistance, ${ }^{65}$ the crime of assault does not arise.

It is therefore submitted that the very nature of ukuthwala is comparable to assault common and assault with intent to cause grievous bodily harm. The carrying away of the girl will always involve some degree of force from the suitor and his friends. ${ }^{66}$ It is submitted that in the two forms of ukuthwala where the girl has not consented to the thwala, all the elements of the crime of assault are manifestly present. It is very difficult to argue that assault is not present. The mere fact that she is taken away against her will is in itself synonymous with the crime of assault because force or threat of force is involved. It must be noted that there is a difference between pretended resistance ${ }^{67}$ which is customarily acceptable for the girl to hold her maidenly dignity, ${ }^{68}$ and the genuine resistance of the girl who does not want to be married to the suitor. Other forms of assault will be briefly discussed below.

\section{Assault with intent to cause grievous bodily harm and ukuthwala}

Assaults involving serious physical injury have always been regarded as more serious than those that merely inspire fear or that involve mere touching or slight bodily injury. ${ }^{69}$ In South Africa, this assault is referred to as assault to cause grievous bodily harm. ${ }^{70}$ All the requirements for an assault set out above apply to this crime, but the distinguishing factor must be the intent to do grievous bodily harm. ${ }^{71}$ Important factors that have to be considered in order to determine whether the accused had the necessary intention to cause grievous bodily harm, is the weapon used, the way in which it was used, the degree of violence, the part of the body where it was aimed, the persistence of the attack and lastly the nature of the injuries, if any. ${ }^{72}$ This crime may be committed even in instances where the injuries are slight. $^{73}$

In the case of $S v$ Mbelu, ${ }^{74}$ it was stated that there must be an intention to do more than inflict the casual and comparatively insignificant and superficial injuries, which ordinarily follow upon an assault. There must be proof of an intention to injure and to injure in a serious respect. ${ }^{75} \mathrm{~A}$ person may be found

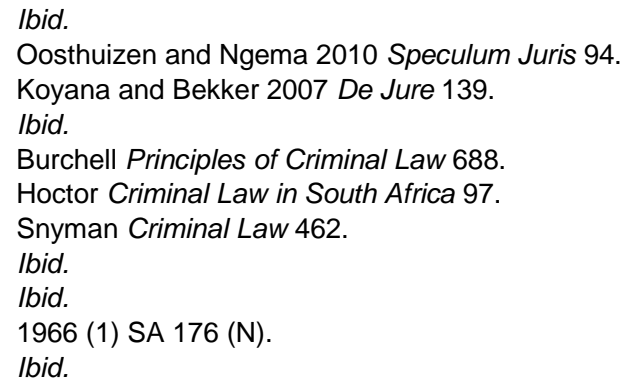


guilty of the offence even if he has not used an instrument like a stick or knife when he attacks the girl but used only his hands or fists. ${ }^{76}$ The accused may be convicted of assault with intent to cause grievous bodily harm on the grounds of not only actually inflicting violence on the girl who is the subject of thwala, but on the grounds of a threat to inflict grievous bodily harm on her. ${ }^{77}$ The rule that applies above is the same as the one in the case of a common assault. ${ }^{78}$

\section{Assault with intent to commit another crime and ukuthwala}

There are various other qualified forms of assault, each constituting a separate offence for an example assault with intent to commit rape. This is more probable in the event of thwala where the suitor assaults the girl in order to rape her in an attempt to persuade her to consent to marriage. ${ }^{79}$ The latter happens in the form of ukuthwala where the girl has not consented and the parents have actually consented to the thwala. ${ }^{80}$ All the requirements for an ordinary assault mentioned above are applicable to these crimes as well. ${ }^{81}$ In some cases that have been studied in Lusikisiki, the suitors had resorted to committing this offence in an attempt to rape and forcefully marry the young girls against their wishes. ${ }^{82}$

\section{Attempted murder and ukuthwala}

In some instances, a suitor will have intercourse with the victim of ukuthwala to coerce her into submitting to marriage, in some cases with the consent of the parent of the victim. ${ }^{83}$ The purpose of a forced sexual intercourse is to create a blood relation between the two parties to persuade the girl to consent to marriage. ${ }^{84}$ In this context, not only is the victim subjected to rape because intercourse is not consensual, but there is also a risk that the perpetrator may be HIV positive and will consequently infect the victim. It is therefore argued that, in the event where the perpetrator is aware of his HIV status but nonetheless engages in sexual intercourse with the victim of thwala, he may be convicted of the offence of attempted murder. This may occur even where there has been consensual sexual intercourse between the two parties. In that regard, there are decided cases one of which is $S v$ Phirl ${ }^{85}$ where the accused had an affair with the complainant and had sexual intercourse with the complainant without using a condom. The trial court in

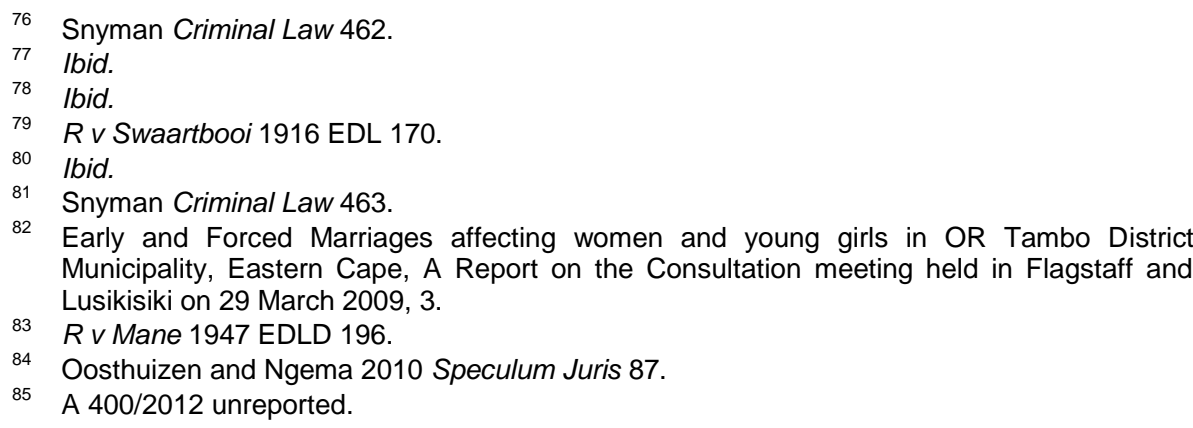


Piet Retief convicted him of attempted murder. ${ }^{86}$ It was found that he had deliberately infected his girlfriend with HIV/AIDS. ${ }^{87}$ The court further held that it was sufficient for the finding of attempted murder, to establish that the appellant, by knowing that he was HIV positive, engaged in sexual intercourse with the complainant whom he knew was HIV negative, without any preventative measures. The conduct of the perpetrator entails the presence of mens rea in the form of dolus eventualis. ${ }^{88}$ The court took judicial notice of the fact that, HIV/AIDS has no cure presently, and thus infection with the virus is likely to lead to a reduced lifespan. ${ }^{89}$

The dangers of this practice of engaging in sexual intercourse without a condom are much more common in the context of thwala due to power relations between the perpetrator and the victim because the sexual intercourse is not negotiated. ${ }^{90}$ It is therefore argued that the perpetrator will be liable for attempted murder over and above other charges. This has been more pronounced in the context of Lusikisiki where elderly men target girls as young as twelve years. In the context of a myth around HIV/AIDS where some men believe that sleeping with a virgin will cure his HIV/AIDS. The common law offence of attempted murder is committed under these circumstances.

In one of the cases in Lusikisiki Regional Court, $S$ v Nkosiyabekwa Mbele ${ }^{91}$ the accused testified to the effect that he targeted the complainant who was fourteen years old because she was a virgin. The victim, in this case, was fortunate that the perpetrator was arrested before consummating the customary marriage. In other case studies, the perpetrators were also charged with attempted murder after having been tested in terms of Chapter 5 of the Sexual Offences Act.

It is therefore important that when a perpetrator is charged with rape, that he be tested for HIV to ascertain his status so that if he wilfully infected the victim with the virus that a second count of attempted murder can be added to the charge sheet. It is argued that one of the primary reasons for men to target young virgin girls is to cure themselves of HIV/AIDS.

\section{STATUTORY CRIMES AND UKUTHWALA}

\section{Sexual Offences and Related Matters Act and ukuthwala}

Sexual violence and the threat of sexual violence go to the core of women's subordination in society. It is the single greatest threat to self-determination

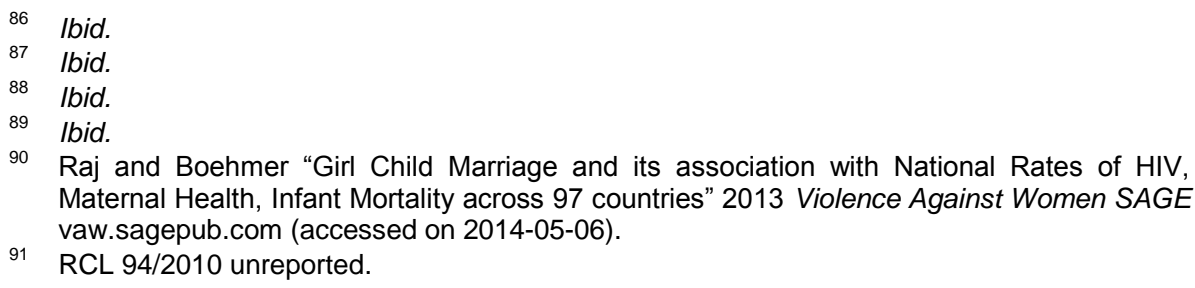

Raj and Boehmer "Girl Child Marriage and its association with National Rates of HIV, Maternal Health, Infant Mortality across 97 countries" 2013 Violence Against Women SAGE vaw.sagepub.com (accessed on 2014-05-06)

91 RCL 94/2010 unreported. 
of South African women. ${ }^{92}$ Rape is a very particular type of assault and, because of its intimate and personal nature, it is a reprehensible form of assault involving not only the application of force to the body of the victim but, by ignoring the victim's unwillingness to engage in sexual intercourse, is a serious invasion of the victim's privacy and autonomy. ${ }^{93}$ The effects of sexual assault such as rape are considerable. ${ }^{94}$ There is the fear of harm experienced by the victim during the rape, accompanied by the realisation that she may contract a sexually transmitted infection or at worst HIV/AIDS. ${ }^{95}$ In the case of the woman she may become pregnant as a result of rape and has to bear the trauma of carrying and raising a child of rape.

The Sexual Offences and Related Matters Act $^{97}$ repeals the common-law crime of rape and replaces it with the expanded statutory crime of rape, which is applicable to all forms of sexual penetration without consent, irrespective of the gender of the perpetrator or the victim. ${ }^{98}$ It repeals the common law crime of indecent assault and replaces it with a statutory crime of sexual assault, applicable to all forms of sexual violations without consent. $^{99}$ The Act creates comprehensive new crimes relating to sexual acts against children and mentally disabled persons.

On 16 December 2007, the Criminal Law Amendment Act ${ }^{101}$ came into operation. It comprehensively consolidated the common law and statutory laws relating to the substantive nature of sexual offences crimes, certain laws of evidence relating thereto and the development of a National Policy Framework that ensures the enhancement and or advancement of processes and procedures for the management of victims and survivors of sexual offences. The latter is very important to the sexual offences arising from the practice of ukuthwala because some of the cases of thwala took place before this Act came into operation. ${ }^{102}$ The cases of sexual offences that took place before this Act came into operation will be dealt with in terms of the common law. ${ }^{103}$

\section{Rape in terms of section 3 of the Sexual Offences and Related Matters Act and ukuthwala}

Section 3 of the Act provides that any person who unlawfully and intentionally commits an act of sexual penetration with another person without the latter's consent is guilty of the offence of rape. ${ }^{104}$ Sexual

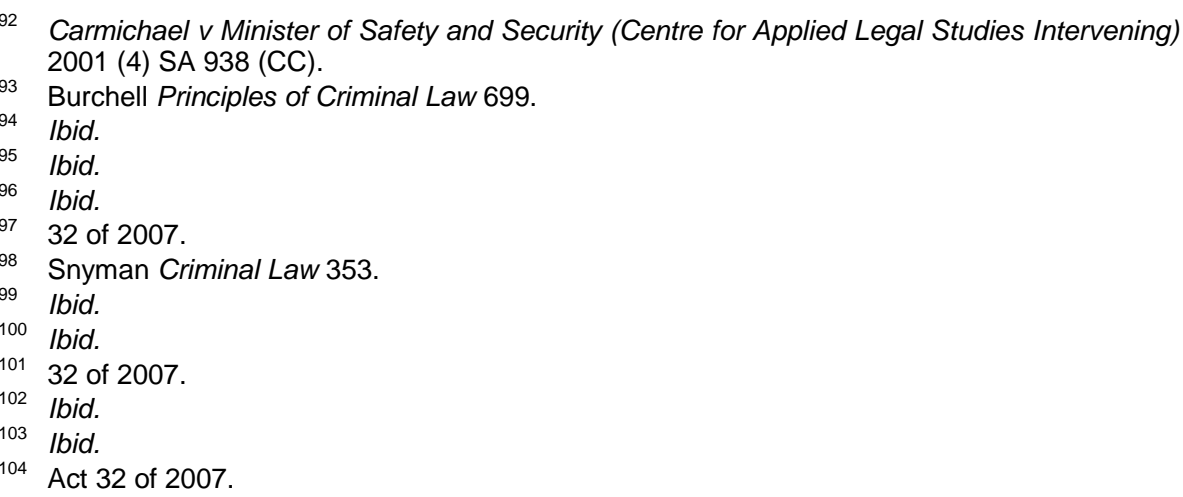


penetration is defined as including any act that causes sexual penetration. ${ }^{105}$ Consent must be voluntary or un-coerced agreement. ${ }^{106}$ Rape is complex and has a wide impact on society. ${ }^{107}$ Rape victims experience many problems such as rape trauma syndrome. ${ }^{108}$ This is a condition that involves the deep disruption of the victim's life patterns and thought processes, not only in terms of the physical effects of rape but also in terms of its effects on the victim's emotional and spiritual well-being, mistrust of surroundings and other people, embarrassment etc. ${ }^{109}$ Rapes are not the same as they differ according to the nature of the relationship between the offender and the victim and some are worse than others. ${ }^{110}$ There are different types of rape, for example, date rape, opportunistic rape, spousal rape etcetera. In the context of ukuthwala, the victim may not even know the suitor who will ultimately rape her. At other times the victim knows the perpetrator but has not consented to sexual intercourse. Therefore rape in the context of ukuthwala is different in that rape is committed in order to compel the victim to agree to a marriage.

In the latter situation, the father of the victim has tacitly consented to sexual intercourse between his daughter and a prospective husband with a view to establishing a connection between the girl and the man so that the girl can get used to the idea of marriage to the suitor. It is submitted that the young man who forces himself on the young woman is liable to be charged with rape because he has intercourse with the girl without her consent. It is submitted further that even if the girl consents, such consent has been given because of force, intimidation, threats and abuse of power or authority. Typically, the use of power or authority in the context of ukuthwala occurs when a father threatens to expel the girl if she refuses to have sexual intercourse with the perpetrator. In one of the case studies undertaken in Lusikisiki, one of the fathers used the very same tactic by saying that if his daughter refuses marriage to the perpetrator, she must know that she is no longer his daughter.

In the first form of ukuthwala where the girl has agreed to the thwala, consent to sexual intercourse is not a factor unless she is below the age of sixteen years. In that case, the perpetrator may be charged with statutory rape. However, in the other two forms where the girl has not consented to thwala and sexual intercourse takes place, rape is committed, regardless of the fact that the father or guardian of the girl has consented. The offence of rape is committed against the actual victim and not the parent or a guardian. In the second form of ukuthwala where the parent has consented to the thwala and sexual intercourse, the parent may be charged for the crime of rape as an accomplice. In the context of the practice referred to as ukuthwala in Lusikisiki involving girls under the age of twelve years, the perpetrator who engages in a consensual sexual intercourse with a minor below that age commits rape. A child below the age of twelve years cannot

\footnotetext{
Snyman Criminal Law 355.

$\mathrm{S} 1(2)$.

Mudau $v$ The State 764/12 (SCA) par 147 unreported.

8 Gordon "Rape Trauma Syndrome in Sexual Assault Cases" 1999 Colorado LR 2509.

S v Bailey 454/11 2012 (SCA) 154 unreported.

$10 S v$ Abrahams 2002 (1) SACR 116 (SCA) par 29.
} 
consent to a sexual intercourse. Similarly, parents who allow their children to engage in sexual intercourse with elderly males will be accomplices to rape.

\section{Sexual assault and ukuthwala}

The crime of sexual assault replaces the common law crime of indecent assault ${ }^{111}$ in terms of section 68(1) (b) of the Act. ${ }^{112}$ Indecent assault consisted of unlawfully and intentionally assaulting, touching or handling another in circumstances in which either the act itself or the intention with which it is committed was indecent. ${ }^{113}$ It covered diverse types of indecent actions, ranging from the actual physical assault of the genital organs of another to a mere touching of the so-called erogenous zones without the consent of the victim.

Section 5 of the Act defines sexual assault as conduct by any person who unlawfully and intentionally sexually violates a complainant without her or his consent. The perpetrator then commits an offence of sexual assault. ${ }^{15} \mathrm{~A}$ person, who unlawfully and intentionally inspires a belief in a complainant that he or she will be sexually violated, also commits an offence of sexual assault. ${ }^{116}$ The elements of this offence are the following: an act of sexual violation of another person, without the consent of such person, unlawfulness and intention.

The purpose of this crime is to criminalise sexual acts which fall short of actual penetration of the victim. ${ }^{118}$ The conduct of ukuthwala can be equated with the conduct required in section 5 . The conduct of the suitor falls within the definition of sexual assault when he touches and inspires a belief in the victim of thwala that sexual violation will take place. This will probably happen in respect of the two forms of ukuthwala where there is no consent from the victim herself as well as the parents. Similarly, in the context of the practice in Lusikisiki, men who target children below the age of twelve years will be liable for committing a crime of sexual assault. Parents who condone the sexual violation of their minor children below the age of twelve years will be liable as accomplices to sexual assault.

\section{Sexual offences against children and ukuthwala}

Chapter 3 of the Act, comprising of sections 15 to 22, deals with sexual offences against children. ${ }^{119}$ The most important of these crimes, which has a serious bearing on the practice of ukuthwala, is intercourse with children under the age of sixteen years, even with their consent. ${ }^{120}$ This offence cuts

\footnotetext{
Snyman Criminal Law 371

32 of 2007.

Snyman Criminal Law 371. 
across all the three forms of ukuthwala, where a victim is a person below the age of sixteen years. In instances of the first form of ukuthwala where the girl below the age of sixteen years has consented, the charge will be statutory rape. ${ }^{121} \mathrm{~A}$ child for purposes of sections 15 to 22 is a person twelve years or older but under the age of sixteen years. In the case of the ukuthwala where there has been no consent from the minor the charge will be one of rape in terms of section 3 of the Act. ${ }^{122}$ In the context of what took place in Lusikisiki where girls younger than twelve years are thwalae'd and subsequently slept with by older men. Section 57 retains the common law position that children under twelve years of age cannot consent to sexual acts. ${ }^{123}$ It is for that reason that the provisions of section 3 of the Act ${ }^{124}$ will come into operation.

It is therefore important to note that conduct of ukuthwala can be equated with rape in terms of section 3 in all forms of ukuthwala even if the minor consented provided that if she is below the age of twelve years, and statutory rape in respect of consensual sexual intercourse with a minor who is older than twelve years and younger than sixteen years of age. In the event of ukuthwala where there is no consent at all regardless of the age, the perpetrator will be liable for an offence of rape. The only defence available to the perpetrator of thwala who had sexual intercourse with consent with the minor child will be that he was deceived into believing that the child in question was sixteen years or older and he reasonably believed that the child was, in fact, older than sixteen years. ${ }^{125}$ The defence will not hold in the event where there has been no consent from the victim of ukuthwala and to the subsequent rape. The court held in the case of De Reuck $v$ Director of Public Prosecutions, Witwatersrand: ${ }^{126}$

"Children merit special protection by the State, the degradation of children

impairs their dignity and contributes to a culture that devalues their worth.

Society has recognised that childhood is a special stage in life which is to be

treasured and guarded, there is obvious physical harm suffered by victims of

sexual abuse.

The latter is very important because children between the ages of twelve and sixteen years are not yet mature enough to appreciate the implications and consequences of sexual acts properly, let alone of marriage. ${ }^{128}$ Children should be protected against unscrupulous men who prey on young girls under the pretext of culture.

Similarly, section 16 of the $\mathrm{Act}^{129}$ criminalises acts of sexual violation of children with their consent. This offence occurs where the child is twelve years or older, but under the age of sixteen and consents to the act of sexual violation, regardless of the sex of the child or the sex of the offender. ${ }^{130}$ The

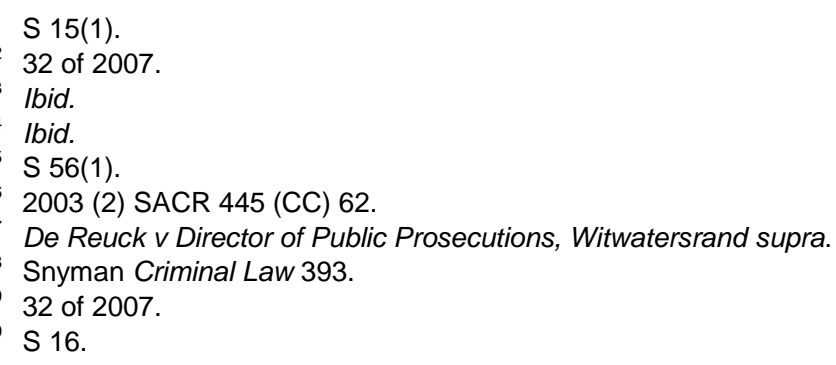


conduct of ukuthwala can be equated with the consensual violation of the child where the child who is the subject of thwala is twelve years or older but under the age of sixteen years and has consented to the thwala and the subsequent sexual violation even if it is consensual. In this situation, the offender should be charged with sexual assault in terms of section 5 of the Act. ${ }^{131}$ This is also true in the second and third form of ukuthwala where there has been no consent from the child, and in such cases, the perpetrator will be charged for statutory sexual violation against the child.

The only defence that the accused can invoke will be in respect of ukuthwala with consent and subsequent violations in terms of sections 15 and 16 where he contends that the child deceived him into believing that she was over the age of sixteen years or older and he reasonably believed that the child was over the age of sixteen years or older. ${ }^{132}$ The defence provided by section 56 will not hold in respect of thwala where there has been no consent from the child.

The Act makes an interim provision relating to the trafficking of persons for sexual purposes. This was pending the promulgation of the Prevention and Combating of Trafficking in Persons by State President signed on 29 July 2015. In the recent past perpetrators take the victims of ukuthwala from the Eastern Cape Province to other provinces like the Western Cape and Gauteng and the case in point is $S v$ Jezile. ${ }^{133}$ In this case, the accused was charged for trafficking in person, assault with intent to cause grievous bodily harm and common assault. ${ }^{134}$ In the case of trafficking in person, the evidence was that the victim was transported from Ngcobo in the Eastern Cape to Cape Town via a taxi to become a wife to the accused. ${ }^{135}$ It is argued that ukuthwala, where a victim is taken from one place to the other can be equated to trafficking in persons.

\section{The Prevention and Combating of Trafficking in Persons Act and ukuthwala}

Trafficking in persons is a global phenomenon that involves obtaining or maintaining labour or services of a person through the use of force, fraud or coercion in violation of an individual human's rights. There are many similarities between trafficking and ukuthwala as seen in previously mentioned case studies and, more importantly, in the case of State $v$ Jezile in the Western Cape Province. The similarities between trafficking and ukuthwala are that victims of ukuthwala are transported from the rural Eastern Cape Province to urban areas of the Western Cape and Gauteng provinces.

Trafficking in persons happens everywhere in the world including South Africa. Victims of trafficking are preyed upon because of their lack of information, poverty and unfavourable socio-economic circumstances. The

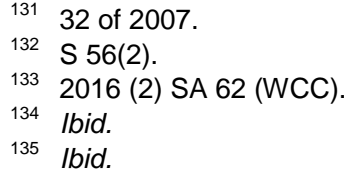


latter can be equated with ukuthwala particularly in the Lusikisiki District where victims are mainly drawn from impoverished backgrounds. They are lured with money, deceived by false promises, abducted, sold by their families and they are exploited. It is therefore argued that trafficking in person and ukuthwala as it relates to minors are synonymous. The slight difference between ukuthwala and trafficking in terms of the Trafficking in Persons Act is that in the case of ukuthwala the victims are transported for sexual exploitation whereas in the Act it is for broader purposes that include labour exploitation, forced military service and for removal of body parts. The other difference is that ukuthwala is mainly targeted at girl children whereas the Act includes boys. Therefore trafficking in terms of the Act is gender neutral. ${ }^{136}$

\section{DEFENCES AGAINST LIABILITY AND UKUTHWALA}

\section{Cultural defence and ukuthwala}

South Africa is not the only country faced with the challenges resulting from a pluralistic legal system. ${ }^{137}$ There are many countries that have pluralistic legal systems. In Ngatayi $v R^{138}$ the High Court of Australia observed:

The existence of systems of law side by side, the prevailing one and aboriginal customary law, with their very different attitudes to guilt and responsibility, creates serious problems and the question how far our laws should apply to aboriginals and how far their law should be allowed to apply to them is controversial.

The South African legal system regularly has to deal with the question of culture in the legal sphere. ${ }^{140}$ Over a period of a hundred and fifty years, a modus vivendi was gradually worked out for South Africa's indigenous customary laws and the imported colonial laws. ${ }^{141}$ However, the relationship was hardly an equal one. ${ }^{142}$ The two systems finally came to be treated on a par only with the arrival of a democratic Constitution. ${ }^{143}$ Section $211(3)$ of the Constitution obliges all the courts to apply customary law when that law is applicable, subject to the Constitution and legislation that specifically deals with customary law. ${ }^{14}$

It seems as if the question between customary and common law has been settled, but an area still to be explored and settled is criminal and customary law. ${ }^{145}$ The criminal law primarily deals with the relationship between the

136 South African Law Commission Project 107 Sexual Offences Discussion Paper 85 Sexual Offences: The Substantive Law 29 October 1999 par 87.

137 Rautenbach and Mathee 2010 Journal of Legal Pluralism 109.

138197930 ALR 27: 36-37.

139 lbid.

140 Rautenbach and Mathee 2010 Journal of Legal Pluralism 111.

141 Bennett "The Cultural Defence and the Custom of Thwala in South African Law" 2010 University of Botswana LJ 3.

142 Ibid.

143 Alexkor Ltd v Richtersveld Community 2003 (12) BCLR 1301 (CC).

144 Constitution of the Republic of South Africa, 1996.

145 Bennett 2010 University of Botswana LJ 4. 
state as prosecuting organ and the criminal a private individual. ${ }^{146}$ The African customary law consists of the unwritten and written laws of the indigenous communities. ${ }^{147}$ Because the customary law is closely identified with African cultural traditions, the courts accepted that its application rested on the constitutional guarantee of culture. ${ }^{148}$

In this regard, an issue that that invites serious consideration is what Anglo-American jurisdictions term a cultural defence. ${ }^{149}$ This defence allows members of a minority culture to argue that they should be completely acquitted of criminal charges, or their culpability be at least mitigated, on the ground that their cultural norms were the reason for the commission of crimes. ${ }^{150} \mathrm{~A}$ critical issue in the cultural defence is a distinction between dominant and minority cultures. ${ }^{151}$ The principal arm of state control is criminal law. ${ }^{152}$ It encodes the state's dominant cultural values and is deemed applicable to everyone. ${ }^{153}$ The dominant regime is therefore extended to the entire population, regardless of the values and practices of the minority groups. ${ }^{154}$ South African courts have never entertained a defence of culture, ${ }^{155}$ an odd omission, because the culture has, on several occasions, been argued in this manner, ${ }^{156}$ and, of course, African culture has long been accepted as part of our legal system.

In South Africa, the most convenient place at which to start an account of customary law is the Law of Evidence Amendment Act. ${ }^{158}$ It provides that: "any court may take judicial notice of indigenous law in so far as such law can be ascertained readily and with sufficient certainty". ${ }^{159}$ The term "indigenous law" is defined broadly by the Act to mean "Black Law or customs as applied by the Black tribes in the Republic or in territories which formerly formed part of the Republic". 160 The courts have always operated on an unspoken assumption that, for criminal matters, only the common law is applicable. ${ }^{161}$ South African criminal law does not provide for a distinct or separate defence based on culture. ${ }^{162}$ Culture plays a role in at least two stages of a criminal case, first during the process of inquiry to ascertain if the

146 Rautenbach and Mathee 2010 Journal of Legal Pluralism 111.

147 Ibid.

148 Bennett Human Rights and African Customary Law under the South African Constitution (1995) 23.

149 Van Broeck "Cultural Defence and Cultural Motivated Crimes" 2001 European Journal of Crimes 9.

150 lbid.

151 Bennett 2010 University of Botswana LJ 4.

152 Ibid.

153 Ibid.

154 Waldron "One Law for All? The Logic of Cultural Accommodation" 2002 Washington and Lee LR 3.

155 Carstens "The Cultural Defence in Criminal Law: South African Perspectives" 2004 De Jure 312.

$156 \quad R$ v Matomana 1938 EDL 131.

157 Bennett 2010 University of Botswana LJ 5.

158 S 1(1) of Act 45 of 1988.

159 S $1(1)$

$160 \mathrm{~S} 1(4)$

161 Bennett 2010 University of Botswana LJ 5.

162 Rautenbach and Mathee 2010 Journal of Legal Pluralism 114. 
general requirements for a particular crime have been met and secondly when a suitable punishment for a convicted accused must be determined. ${ }^{16}$

\section{Defence of ignorance or mistake of law and ukuthwala}

Before the landmark decision of the Appellate Division in $S v$ De Blom, ${ }^{164}$ the rule that ignorance or mistake of the law is no excuse prevailed, even if it was unavoidable or excusable. ${ }^{165}$ The general rule underlying this principle was expressed in the maxims inherited from the English law, whose essence is that everybody is presumed to know the law. ${ }^{166}$ The ignorance and mistake of the law rule still forms a fundamental part of the Anglo-American law, ${ }^{167}$ although exceptions to this harsh rule have been recognised in certain instances, ${ }^{168}$ and academics and commentators have argued for a more lenient approach to ignorance and mistake of the law. ${ }^{169}$

The Anglo-American systems of criminal justice do not admit the defence of mistake of law. ${ }^{170}$ It is submitted in those jurisdiction that familiarity with the provisions of the law is part of a citizen's civic responsibility. ${ }^{171}$ However, fairness and justice, particularly in respect of the countless, and evergrowing number of statutory offences, clearly demands that genuine ignorance or mistake of law should exclude intention. ${ }^{172}$ The logic of requiring intention with regard to every element of a crime including unlawfulness is not alone sufficient to demand this conclusion but when demands of logic and principle then the challenge to the ignorantia juris rule is a fundamental one. ${ }^{173}$

The unanimous Appellate Division decision in $S v$ De Blom ${ }^{174}$ boldly swept the ignorantia juris rule from our criminal law in line with principle and logic. ${ }^{75}$ Knowledge on the part of the accused of the unlawfulness of his or her conduct is now always a requirement of mens rea in the form of intention. ${ }^{176}$ It follows that ignorance or mistake of law invariably negatives mens rea in respect of the unlawfulness element and hence excludes liability. ${ }^{177}$ Therefore the defence of mistake or ignorance of the law is perfectly acceptable in South African criminal law. ${ }^{178}$ In crimes where only dolus suffices, the accused may rely on mistake of law in the same way as

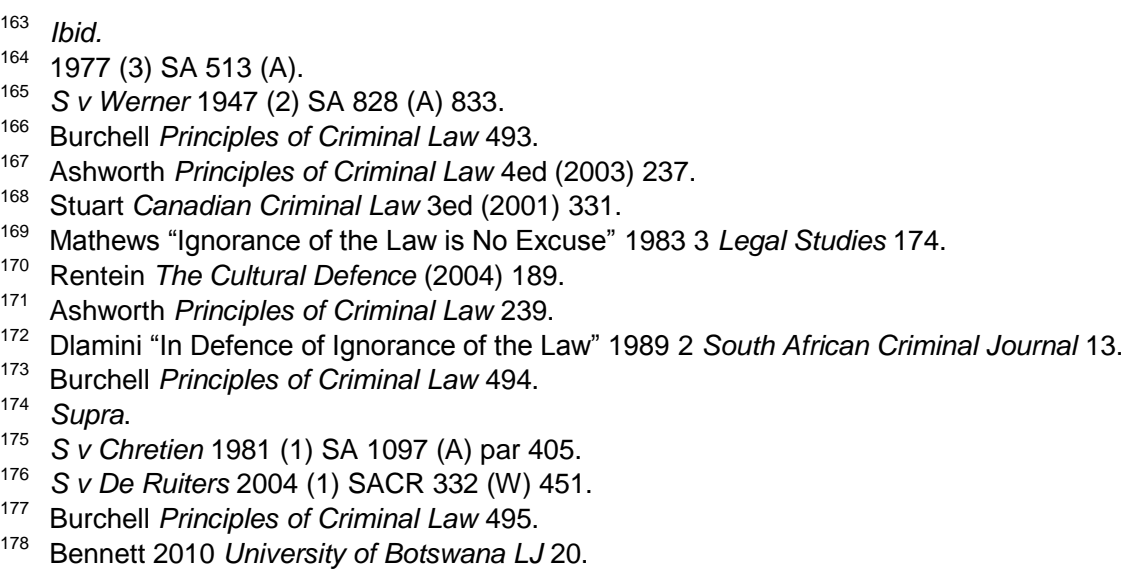


mistake of fact, provided that it can be reasonably inferred that he or she honestly did not know that the act was unlawful. ${ }^{179}$ Hence, someone charged with abduction, rape, or assault would be entitled to argue an honest belief that the act was lawful in terms of the custom of thwala.

Didcott $\mathrm{J}$ stated in $S v$ Waglines ${ }^{181}$ that "the defence of ignorance of the law has been pleaded, during the decade ensuing since then, if not by every man then at least by a goodly number" ${ }^{182}$ It is submitted that the defence has not posed major practical difficulties. ${ }^{183}$ Rumpf CJ in De Blom stated that a person who works in a particular sphere of activity ought to know the law relating to that activity. ${ }^{184}$ If the person does not know the regulations relating to his or her sphere of activity could be adjudged negligent. ${ }^{185}$ In $S V$ Molubi $^{186}$ the court convicted the accused of a crime requiring intention despite the fact that, because of mistake of law, he was ignorant of the material provisions of the law. ${ }^{187}$ The court based its decision on the consideration that the accused had embarked on a specialised activity, the person who does this should take steps to acquaint himself with the law applicable to such activity, and that the accused had failed to do this and should accordingly not succeed with a defence of ignorance of the law. ${ }^{18}$

In the event, intention is required, the inquiry is purely subjective and so the fact that the accused ought to know the law pertaining to a particular activity is only of evidential value in determining whether the accused's ignorance or mistake of law is genuine or not. ${ }^{189}$ To this end, the burden of proof rests on the accused. ${ }^{190}$ The meaning of knowledge in respect of unlawfulness does not lead to any difficulty when it is appreciated that unlawfulness is merely one of the elements of crime in respect of which mens rea must now always be proved. ${ }^{191}$ It follows that knowledge of unlawfulness will be present where the accused has intention in respect of unlawfulness in the usual meaning of that term in criminal law. ${ }^{192}$ It need not, therefore, be shown that the accused actually know his conduct is unlawful. ${ }^{193}$ It is sufficient if he foresees the possibility ${ }^{194}$ of such unlawfulness $^{195}$ and yet proceeds, reckless as to whether it is or not. ${ }^{196}$

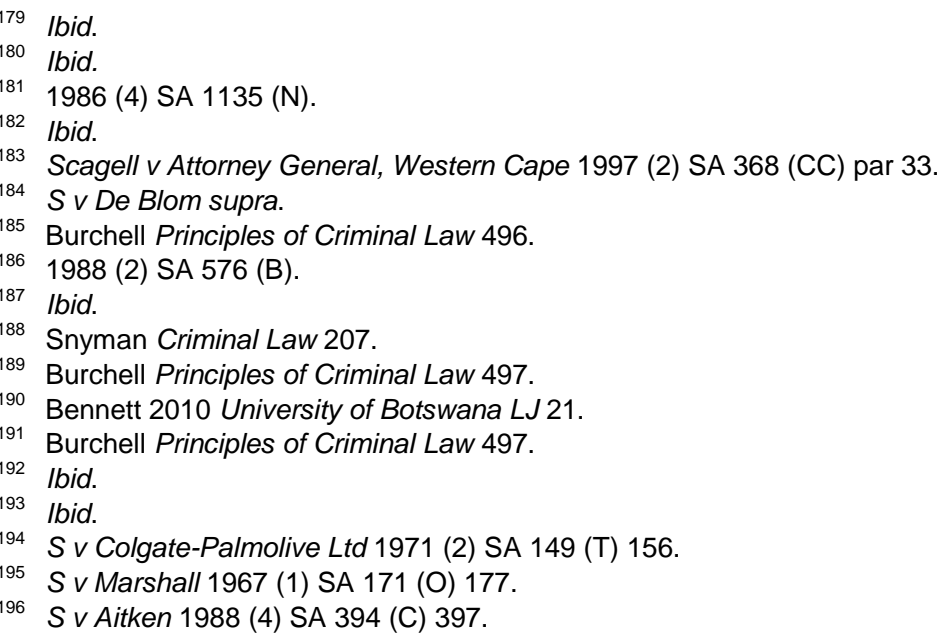


Knowledge of unlawfulness or wrongfulness ${ }^{197}$ means that where the crime requires mens rea in the form of intention, liability is invariably dependent upon the accused having known that he or she is acting in contravention of the law. ${ }^{198}$ It is not necessary to prove that he knows the detailed requirements of the offence charged, or the exact section or wording of the law in question, or the penalty for transgression, but merely that he knows, or at least foresees the possibility, that what he is doing is contrary to law in the broad sense. ${ }^{199}$ In $S$ v Hlumza ${ }^{200}$ Corbett JA held that the appellant, who was charged with dealing in a prohibited substance producing drug, did not have to know that the tablets contained methaqualone, nor did he have to know what statute was being contravened or what the precise provisions of the law might be. ${ }^{201}$ The court held that it was sufficient if he knew that possession or dealing in tablets in question was or might possibly be, unlawful. ${ }^{202}$

It is submitted that in the context of thwala of minor children by adults the defence of mistake of law or ignorance will not arise. It is based on the reasons advanced by Corbet JA in the Hlumza case because the accused ought to know that the person that he seeks to marry is a minor and without knowing the exact age of the victim. It is sufficient if he knows that the victim is below the age of eighteen years and the thwala may possibly be unlawful. However, in instances where the thwala involves a major woman and the accused bona fide believes that he is engaging in thwala the defence will suffice.

\section{$6 \quad$ CONCLUSION}

The practice of ukuthwala as it is currently practised is a distorted version of the age-old traditional practice of ukuthwala. Ukuthwala in its traditional form did not target young girls but is a condoned, abnormal path to marriage targeted at certain women of marriageable age. ${ }^{203}$ The principle of Ubuntu was the underlying pillar of ukuthwala, whose main ethical values are respect for others, including women and children, helpfulness, community, caring, trust and selflessness. ${ }^{204}$ Morals such as compassion, cooperation and communalism are highly valued and the whole community is a unified objective. ${ }^{205}$

As currently practised, ukuthwala involves kidnapping, rape, forced marriages of minor girls, assault and all related criminal offences. It contradicts the very principles of Ubuntu that have characterised African communities over the years. More importantly in this day and age of constitutional democracy, it has become an affront to women and children

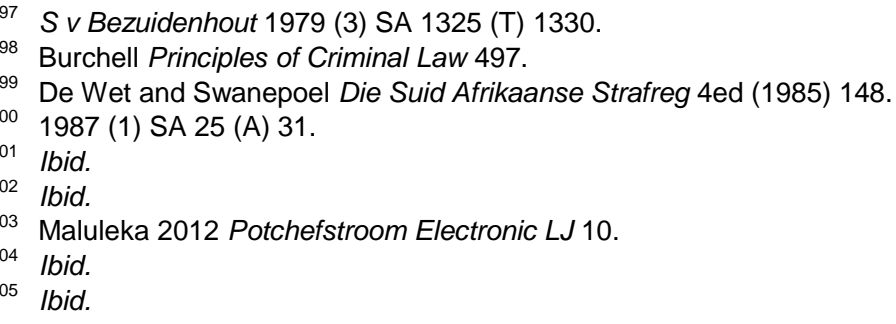


rights as enshrined in the Bill of Rights. It is argued that ukuthwala is not in itself a criminal offence. However, the facts of recent cases where criminal prosecutions were instituted manifest a serious challenge in how this tradition is currently practised in some parts of South Africa. The cases studied show that the practice as implemented in Lusikisiki, borders on the commission of very serious offences. It is therefore within that context that it is argued that the practice of ukuthwala cannot be used as a defence in a criminal matter where an accused faces a case of rape, regardless of the age of the victim if consent was not given for sexual intercourse with the victim.

Neither could it be a defence for any criminal offence arising from the purported thwala practice in any criminal matter where the victim has laid a criminal charge against the perpetrator.

It is submitted that South Africa does not need specific legislation to deal with the practice of ukuthwala. The common law has shown that, together with other statutory provisions that deal with conduct arising from the thwala practice, there is a sufficient to adequate response to the problem. It is further submitted that enacting a specific piece of legislation will not serve any purpose in dealing with the practice as it is currently seen in some parts of South Africa. A few cases that have been successfully prosecuted bear testimony to the fact that the common and statutory provisions are enough to respond to the scourge. It is submitted that since the prosecution of cases, both in the Eastern and Western Cape provinces, a long way had gone in dissuading would be offenders. Since those prosecutions, there has been a dramatic decrease in the number of cases reported as a result of the distorted application of ukuthwala.

The proper education of the community and traditional leaders on respect for human rights, as well as bringing up boys with values to respect women, will go a long way to create a human rights culture wherein the traditional ukuthwala can still be practised with the consent of the girl and her family.

It is submitted that the training will empower traditional leaders to become more vigilant and knowledgeable in terms of how to interface with the South African Police Services without compromising their traditional leadership roles. In this way, the role of traditional leadership will be enhanced in terms of ensuring that the positive development of customary law is vested in skilled and educated leaders. 